\title{
sciendo

\section{Life Cycle Assessment of Foam Concrete Production in Latvia}

\author{
Zinta ZIMELE ${ }^{1 *}$, Maris SINKA ${ }^{2}$, Aleksandrs KORJAKINS ${ }^{3}$, \\ Diana BAJARE ${ }^{4}$, Genadijs SAHMENKO ${ }^{5}$ \\ ${ }^{1-5}$ Institute of Materials and Structures, Riga Technical University, Kalku iela 1, Riga, LV-1658, Latvia
}

\begin{abstract}
Global warming being increasingly discussed, solutions for reducing emission greenhouse gases become more important in all industry sectors. The total energy consumed in the construction sector contribute up to $1 / 3$ from all greenhouse gases emissions. Large part of it comes from the cement production $-5 \%$ of the total global emissions. The foam concrete is lightweight concrete with good thermal properties and ability to reduce $\mathrm{CO}_{2}$ emissions by reducing the use of cement due to its low density. The aim of this study is to determine impact on the environment with the use of Life Cycle Assessment (LCA) with focus on Global Warming Potential (GWP) for two different compressive strength foam concrete mixtures produced in Latvia by unique intensive mixing technology - turbulence with cavitation effect. Afterwards, the selected foam concrete mixtures are compared with alternative materials with similar compressive strength - aerated concrete and hollow ceramic blocks. The foam concrete mixture having 12.5 MPa compressive strength showed higher $\mathrm{CO}_{2}$ emissions than hallow ceramic block. The majority of $\mathrm{CO}_{2}$ emissions comes from the Portland cement, which is a key element in its composition. On the other hand, the foam concrete mixture having 2.4 MPa compressive strength showed higher $\mathrm{CO}_{2}$ emissions than aerated concrete block. The majority of $\mathrm{CO}_{2}$ emissions are due to foam glass granules, which is the main element contributing to the increased insulation properties of the material. Comparison of each foam concrete with analogue building material by compressive strength shows that the chosen foam concrete mixtures produce greater GWP than alternative materials. This research allows to identify the environmental impacts of different foam concrete mixture components and to improve these mixtures to achieve similar properties with less impact, for example, by replacing foam glass granules with granules made from recycled glass or replacing cement with flay ash, silica fume or recycled glass powder.
\end{abstract}

Keywords - $\mathrm{CO}_{2}$ emissions; foam concrete; global warming potential; life cycle assessment

\section{INTRODUCTION}

The governments of different countries worldwide think about the reduction of pollution in the environment, by creating educational campaigns for the public and by identifying sectors of industry and the development of policy and methodology for environmental pollution control. The construction sector generates up to $30 \%$ of global annual greenhouse gas emissions and consumes up to $40 \%$ of all energy [1]. Large proportion of the $\mathrm{CO}_{2}$ emissions result from the manufacture of building materials mostly coming from the use of fossil fuels [2].

\footnotetext{
* Corresponding author.

E-mail address: zinta.zimele@rtu.lv
}

(C)2019 Zinta Zimele, Maris Sinka, Aleksandrs Korjakins, Diana Bajare, Genadijs Sahmenko.

This is an open access article licensed under the Creative Commons Attribution License (http://creativecommons.org/ licenses/by/4.0), in the manner agreed with Sciendo. 
Consequently, the European Union has several official documents and guidelines aimed at reducing $\mathrm{CO}_{2}$ emissions up to $20 \%$ by 2020 [3], up to $40 \%$ by 2030 [4] and the energy performance of Buildings Directive that requires all new buildings to be nearly zero-energy buildings by the end of 2020 [4]. Such political instruments call for a solution in the construction sector involving improvement and development of building materials in order to reduce the impact on the environment, such as timber construction, straw bale wall panels [5], hemp concrete [6] and green concrete. The definition of green concrete is a concrete, that either uses waste material in its mixture or other production process that lowers its environmental impact, or it has high performance and sustainable life cycle [7]. Knowing that the concrete contains approximately $12 \%$ of cement and the cement industry contributes $5 \%$ of the whole global emission [8], the green concrete is an opportunity for bringing changes into the concrete industry. In this case the foam concrete belongs to the wider class of lightweight concrete and can be considered as a green concrete [8].

Foam concrete is a type of concrete that typically consists of cement, water, preformed foam and fine sand together with other sand-like fine particles, such as fly ash or silica fume [9]. It is possible to reduce the impact of the cement component on the total environmental impact of the material by replacing the amount of cement with the recycled glass powder in an optimal way. Namely, by replacing $20 \%$ of cement with $20 \%$ of the recycled glass powder [10]; by combining the amount of cement with flay ash and silica fume [11]. The foam components mixed with the cement paste give rise to the development of a system of air-voids in the underlying material microstructure - which improves thermal insulation properties. The density of foam concrete is generally ranging from $200-1800 \mathrm{~kg} / \mathrm{m}^{3}$ [12]. This paper discusses two different foam concrete compositions with their compressive strength included in the name of composition. One of them is FC-2.4 with density $445 \mathrm{~kg} / \mathrm{m}^{3}$ and low compressive strength of $2.4 \mathrm{MPa}$ and thermal conductivity $0.11 \mathrm{~W} /(\mathrm{mK})$, in this mixture insulation properties is increased by using foam glass granules and using less Portland cement (1/3 of mix) by adding the fly ash. The second composition is FC-12.5 with density $1150 \mathrm{~kg} / \mathrm{m}^{3}$ and higher compressive strength $12.5 \mathrm{MPa}$ and thermal conductivity $0.28 \mathrm{~W} /(\mathrm{mK})$, using nearly $1 / 2$ Portland cement of total mixture to increase the compressive strength. Compressive strength is used as a comparative unit in order to compare foam concrete with analogue material.

The aim of this study is to examine the environmental impact for the foam concrete produced with intensive mixing technology - turbulence with cavitation effect - which is a patented technology coming from Russia. This unique technology provides the material with homogeneous properties and it is applied in a local plant in Latvia. This study explores the environmental impact of foam concrete in the product manufacturing process using a life cycle assessment. According to the comprehensive review of $\mathrm{CO}_{2}$ emissions from foam concrete it can be seen than from $1 \mathrm{~kg}$ of foam concrete with $900 \mathrm{~kg} / \mathrm{m}^{3}$ there are $0.322 \mathrm{~kg}$ of $\mathrm{CO}_{2}$ eq. and from $1 \mathrm{~kg}$ of foam concrete with density $600 \mathrm{~kg} / \mathrm{m}^{3}=0.467 \mathrm{~kg} \mathrm{CO}$ eq. [13]. There is a limited amount of information available with regard to further development and improvement of foam concrete mix components to reduce its environmental impact. Life cycle assessment (LCA) is a tool that can be used to answer questions related to environmental impacts of materials and products. It is a comprehensive tool, addressing the entire life cycle, and addressing the full spectrum of environmental impacts [14].

The LCA involves determining the potential impact by collecting input or output data for a product or process system throughout its entire life cycle. This study includes information about the production phase. The research is conducted by using LCA program SimaPro 8, which corresponds to the following standards - ISO 14040: Principles and Framework and ISO 14044: Requirements and Guidelines [15], [16]. SimaPro provides many lifecycle 
inventory (LCI) databases, including the renowned Ecoinvent v3 database (covering over 10000 processes) [17], the new industry-specific Agri-footprint database and the ELCD database. SimaPro contains various impact assessment methods, which can be used to calculate impact assessment. In this research CML-IA baseline V3.04 method is used. This CML method is created in the University of Leiden in the Netherlands in 2001 and contains more than 1700 different flows. [18] Generally, this CML method is divided into baseline and non-baseline, the baseline being the most common impact categories used in LCA, and this CML-IA baseline method is used in this research.

The CML-IA baseline method has several impact categories. The main impact category, which is examined in this research, is Global Warming Potential (GWP), which express climate change by the emission of greenhouse gases like carbon dioxide $\left(\mathrm{CO}_{2}\right)$ and methane $\left(\mathrm{CH}_{4}\right)$ and it is measured in $\mathrm{CO}_{2}$ equivalents [17], [19]. One of impact categories is the acidification potential focusing on gases causing acid deposition such as sulphur dioxide $\left(\mathrm{SO}_{\mathrm{x}}\right)$, ammonia $\left(\mathrm{NH}_{3}\right)$ and nitrogen oxides $\left(\mathrm{NO}_{\mathrm{x}}\right)$. The impact category abiotic depletion potential refers to the consumption of non-biological resources such as fossil fuels, minerals, metals, water, which is measured in MJ, but non-fossil re-sources are expressed in $\mathrm{kg}$ antimony equivalent $-\mathrm{kg} \mathrm{Sb}$ equivalent. The human toxicity potential is calculated as index of chemicals released in the environment, such as arsenic, sodium dichromate, and hydrogen fluoride, which are dangerous to human's health. The ozone layer depletion potential indicates the damage of various gases into stratospheric ozone, for example all chlorinated and brominated compounds reduce ability to prevent ultraviolet light entering the atmosphere. The photochemical oxidation is a pollution of photochemical ozone caused by various compounds, such as carbon monoxide $(\mathrm{CO})$, sulphur dioxide $\left(\mathrm{SO}_{2}\right)$, nitrogen oxide $(\mathrm{NO})$, ammonium and NMVOC (non-methane volatile organic compounds). The impact category eutrophication is based on concentration of chemical nutrients (ammonia, nitrates, nitrogen oxides and phosphorous) in ecosystem which leads to severe reductions in water quality and animal populations. The ecotoxicity has been based on maximum tolerable concentrations for ecosystems caused by heavy metals.

In this research LCA is a tool to examine foam concrete in life cycle assessment stage "cradle-to-gate" including assessment for each of its components in order to provide possibilities for developing foam concrete with less impact in environment.

\section{MATERials AND MethodS}

The foam concrete used in this study is produced by a local producer and the components of the concrete mix are already optimized for foam concrete in previous studies [20], [21]. In this study, two foam concrete mixes with different compressive strength $12.5 \mathrm{MPa}$ with density $1150 \mathrm{~kg} / \mathrm{m}^{3}$ and $2.4 \mathrm{MPa}$ with density $445 \mathrm{~kg} / \mathrm{m}^{3}$ and different thermal conductivity (Table 1) is analysed with regard to its impact on the environment. The LCA calculation program SimaPro 8 was used to model these foam concrete materials and analyse their "cradle-to-gate" life cycle, using the Ecoinvent 3.0 database for the majority of processes related to the production of materials. The calculations have been made according to the CML-IA baseline V3.04 method, including one of the categories included in the Intergovernmental Panel on Climate Change (IPCC 100a) Second Assessment Report global warming potential (GWP). The results for the foam concrete according to the LCA calculations were compared with those of analogous materials having similar compressive strength. 


\subsection{Material}

The main parameters of foam concrete are compressive strength and thermal conductivity. Compressive strength is selected as the main criteria to be able to compare these two materials with analogous material with regard to their compressive strength: dense material has higher compressive strength; porous material is with better thermal insulation properties. For the purposes of this study, foam concrete mix FC-12.5 having high strength of $12.5 \mathrm{MPa}$ and a medium thermal conductivity $-\lambda$ value $0.28 \mathrm{~W} /(\mathrm{mK})$ and foam concrete mix FC-2.4 having low strength of $2.4 \mathrm{MPa}$ and better thermal conductivity $-\lambda$ value $0.11 \mathrm{~W} /(\mathrm{mK})$ were selected.

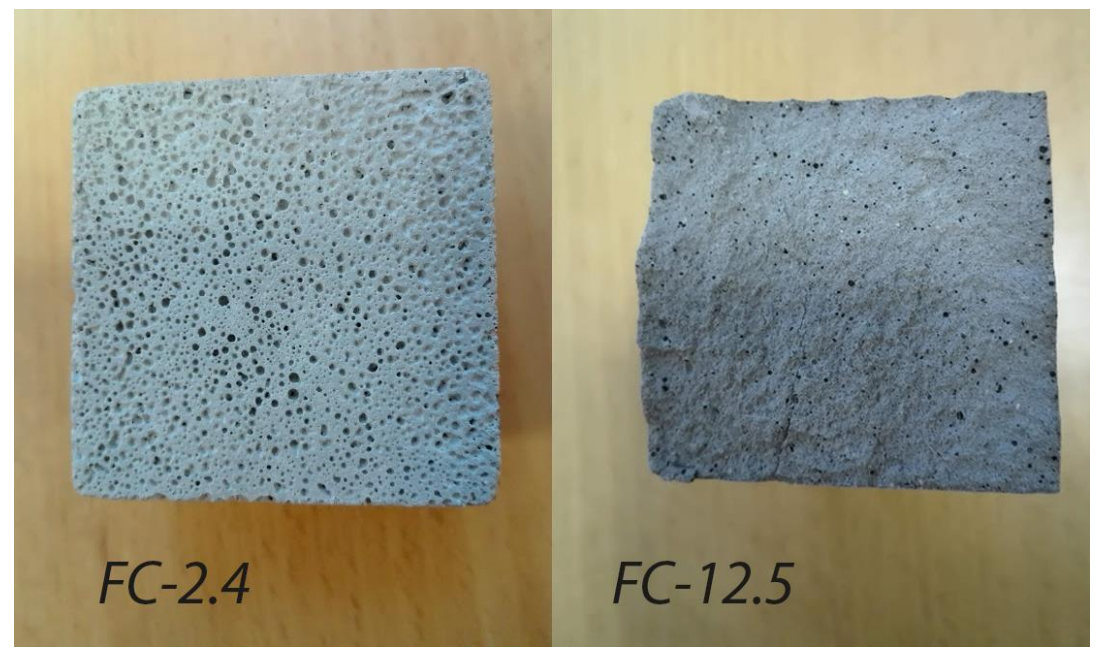

Fig. 1. Foam concrete FC-2.4 and FC-12.5.

TABLE 1. FOAM CONCRETE COMPOSITIONS FC-12.5 AND FC-2.4 FOR 1M ${ }^{3}$

\begin{tabular}{lll}
\hline & FC-12.5, components, kg & FC-2.4, components, $\mathbf{k g}$ \\
\hline Portland cement CEM I 42.5 N & 530 & 148 \\
Sand, fraction 0/1 mm & 303 & \\
Fly ash (cenospheres) & & 74 \\
Water & 246 & 89 \\
Polypropylene fibres EUROFIBER REF 512 & 1.9 & 2.81 \\
Metakaolin* & 38 & 7.4 \\
Silica fume (Elkem 971Dens) & 26.3 & 5.9 \\
Foam glass granules 4/8 mm & - & 118 \\
Plasticizer (polycarboxylate) & 4 & - \\
Density, kg/m & 1150 & 445 \\
Thermal conductivity $\lambda, \mathrm{W} /(\mathrm{mK})$ & 0.28 & 0.11 \\
\hline
\end{tabular}

*Metakaolin in program SimaPro is used as kaolin with added processing energy to obtain metakaolin. Metakolin is obtained from approximately $1.2 \mathrm{~kg}$ of kaolin by calcination in a $750{ }^{\circ} \mathrm{C}$ temperature [22].

\subsection{Data Selection for Life Cycle Assessment Analysis}

In order to ensure robust LCA for the foam concrete, the input data regarding the production of foam concrete are defined manually in the SimaPro program. The data regarding 
production were obtained from the local foam concrete production unit. The provided data referring to the production of $150 \mathrm{~m}^{3}$ of foam concrete in one day are shown in Table 2 . This specific foam concrete production plant is equipped with intensive mixing technology turbulence mixer with cavitation effect (Fig. 2). This method of intensive mixing has many advantages, such as it provides homogenous mix, promotes accelerated hydration and effective use of cement, and keeps together fine aggregate and agglomerated cement [5]. This intensive mixing technology is unique and there is only plant in Latvia having this patented technology.

\section{TABLE 2. THE ENERGY OF FOAM CONCRETE PRODUCING}

\begin{tabular}{llll}
\hline Intensive mixing technology - turbulence with cavitation effect & 12 & $\mathrm{~kW} / \mathrm{h}$ & 1 workload \\
Supply dispenser & 10 & $\mathrm{~kW} / \mathrm{h}$ & 1 workload \\
Conveying belt & 5 & $\mathrm{~kW} / \mathrm{h}$ & 0.5 workload \\
Forklift & 10 & $\mathrm{~kW} / 24 \mathrm{~h}$ & \\
Water heating and supply & 20 & $\mathrm{~kW} / \mathrm{h}$ & 1 workload \\
Other equipment & 4.5 & $\mathrm{~kW} / \mathrm{h}$ & 1 workload \\
\hline
\end{tabular}

Summarizing the data from the table, the total amount of energy necessary for producing $150 \mathrm{~m}^{3}$ per day is $1186 \mathrm{~kW}$.

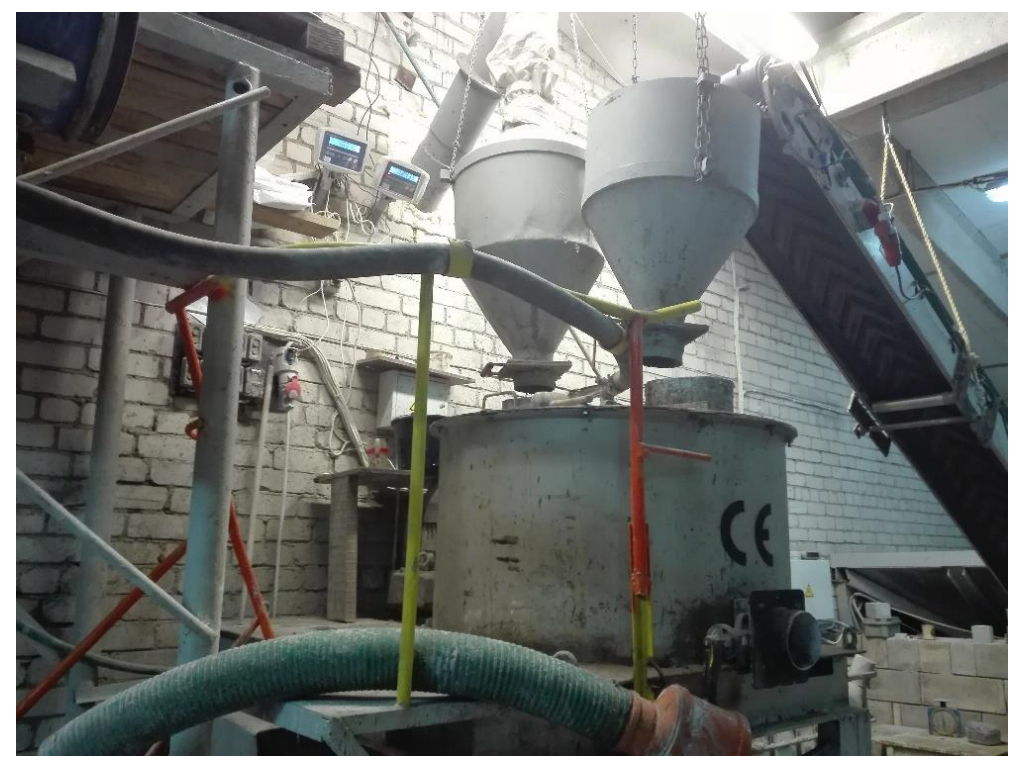

Fig. 1. Turbulence mixer with cavitation effect in the foam concrete plant (intensive mixing technology).

\section{RESULTS AND DisCUSSION}

\subsection{Life Cycle Assessment and Result Interpretation for the Foam Concrete FC-12.5}

After the LCA, it is possible to analyse separately the emissions generated by the FC-12.5 functional units and its separate processes (Fig. 3). The calculations are made for $1 \mathrm{~kg}$ of foam 
concrete FC-12.5 "cradle-to-gate" - in SimaPro program for LAC calculation inputs are defined in one $\mathrm{m}^{3}$ material, but the result is viewed in $1 \mathrm{~kg}$. As mentioned earlier, the main impact category, which is examined in this research, is Global Warming Potential (GWP), which express climate change by the emission of greenhouse gases like carbon dioxide $\left(\mathrm{CO}_{2}\right)$ and methane $\left(\mathrm{CH}_{4}\right)$ and it is measured in $\mathrm{CO}_{2}$ equivalents. The total calculated $\mathrm{CO}_{2}$ emissions from $1 \mathrm{~kg}$ of $\mathrm{FC}-12.5$ are $0.44 \mathrm{~kg} \mathrm{CO}_{2}$ eq. Fig. 3 shows that Portland cement (in orange) emissions represent the largest share of global warming potential (GWP), which is $0.415 \mathrm{~kg} \mathrm{CO}_{2}$ eq. Material FC-12.5 consists of $46 \%$ Portland cement component which is the key element to increase compressive strength, and it accounts for about $94 \%$ of total $\mathrm{CO}_{2}$ emissions from the material, that is mainly due to the energy consumption related to the production of Portland cement.

TABle 3. PERCENTAge COMPARISON OF FoAm

CONCRETE FC-12.5 COMPOSITION BY $\mathrm{CO}_{2}$ EMISSIONS

\begin{tabular}{lll}
\hline FC-12.5 composition & $\begin{array}{l}\text { Percentage breakdown by } \\
\text { components of mass, } \%\end{array}$ & $\begin{array}{l}\text { Percentage breakdown by } \mathrm{CO}_{2} \\
\text { emissions in impact category GWP, \% }\end{array}$ \\
\hline Portland cements CEM I 42.5 N & 46.1 & 94.07 \\
Sand, fraction 0/1 mm & 26.3 & 0.72 \\
Water & 21.4 & 0.02 \\
Polypropylene fibres EUROFIBER REF 512 & 0.2 & 0.88 \\
Metakaolin & 3.3 & 2.4 \\
Silica fume (Elkem 971Dens) & 2.1 & 0.01 \\
Plasticizer (polycarboxylate) & 0.3 & 1.05 \\
Plant power & - & 0.85 \\
\hline
\end{tabular}

The small amount of metakaolin (3.3\%) in the material accounts for $2.4 \%$ of the $\mathrm{CO}_{2}$ emissions. At the same time, the energy consumption from the intensive mixing technology used in the production of FC-12.5 has an insignificant impact on the GWP criteria. It is $0.004 \mathrm{~kg} \mathrm{CO}_{2}$ eq., which accounts for about $0.01 \%$ of the material. The percentage is shown in Table 3.

Looking through all emissions of impact criteria from $1 \mathrm{~kg}$ of foam concrete it is obviously small comparing with electronic devices industry, which is developing and its production volumes are increasing, for example, any Lithium-Ion rechargeable battery of a mobile phone which is used regularly. The one Lithium-Ion rechargeable battery has more than 450 times bigger impact with regard to the human toxicity than $1 \mathrm{~kg}$ of foam concrete. The human-toxicity value from one Lithium-Ion battery is $7.38 \mathrm{~kg} 1.4-\mathrm{DB}$ eq. [23], and from $1 \mathrm{~kg}$ of foam concrete it is $0.0163 \mathrm{~kg} 1.4-\mathrm{DB}$ eq. 


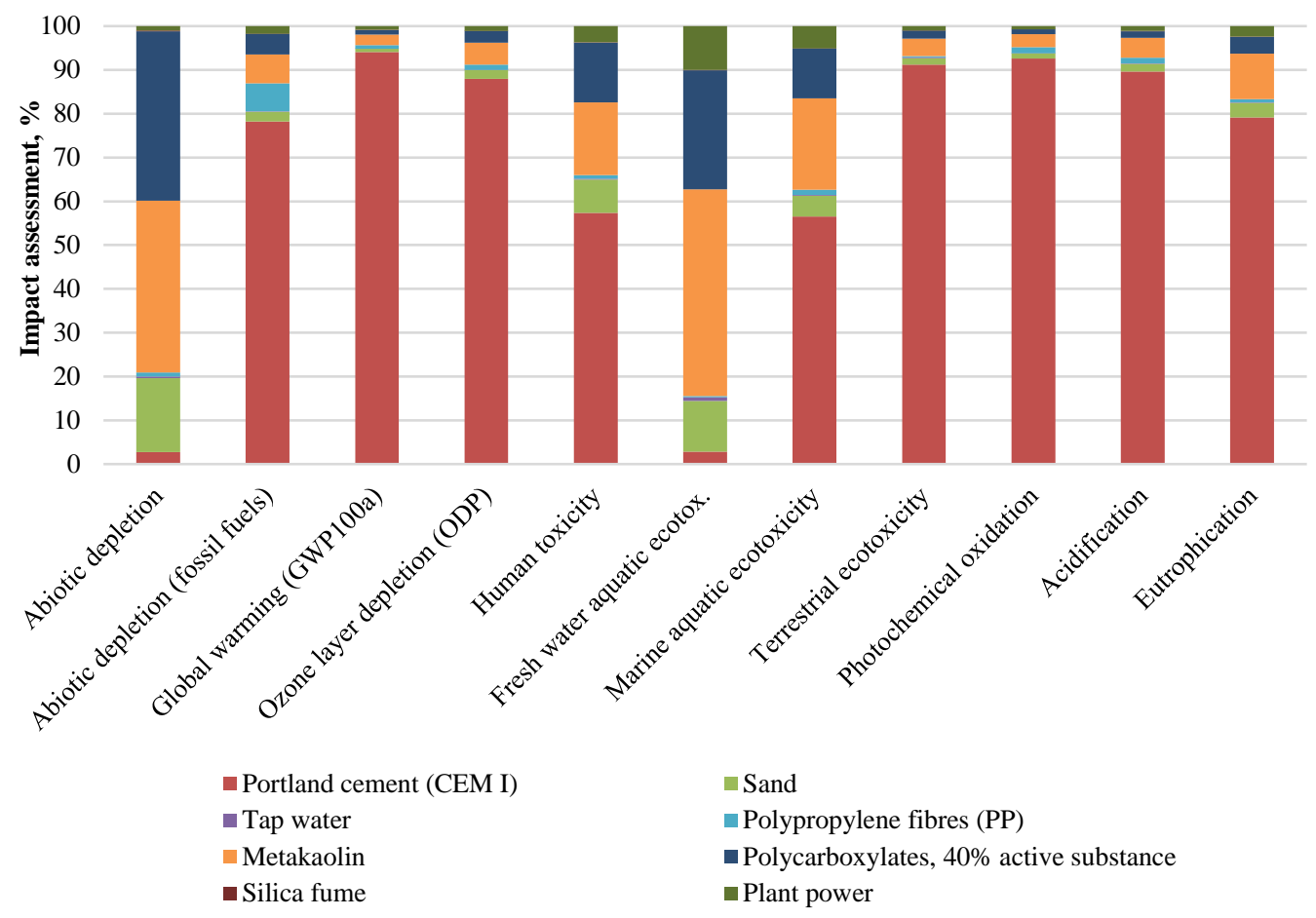

Fig. 3. Foam concrete FC-12.5 impact assessment by CML-IA baseline V3.04/EU25.

\subsection{Comparison of the Foam Concrete FC-12.5 with Hollow Ceramic Block According to the Life Cycle Assessment}

The foam concrete FC-12.5 is compared to an analogous building material chosen according to the strength of the material. FC-12.5 in this study is compared to a hollow ceramic block [24] fulfilling the required criteria for strength - building block, Keraterm 38, strength, $12.5 \mathrm{MPa}$ with a density $783 \mathrm{~kg} / \mathrm{m}^{3}$ and thermal conductivity $0.13 \mathrm{~W} /(\mathrm{mK})$. The hollow ceramic block is a lightweight brick. The hallow ceramic block is produced from the clay, which is mixed with water and forced through an opening, forming and creating cells. After forming it is cut in the necessary dimensions, hardened by drying at $50-150{ }^{\circ} \mathrm{C}$ and then calcined [25]. The hollows in ceramic blocks reduce the use of clay to produce the material, and also increase their thermal performance. Hollow bricks are lighter compared with clay bricks, easier to handle and usually used in single-wall constructions.

The obtained results are shown in the graph (Fig. 4) and Table 4, which shows a comparison between the foam concrete FC-12.5 and the hollow ceramic block. The selected unit for comparing both materials is $1 \mathrm{~m}^{3}$. According to the environmental impact criteria GWP, it can be seen that $1 \mathrm{~m}^{3}$ of the FC-12.5 material produce $508 \mathrm{~kg} \mathrm{CO}_{2}$ eq., but hollow ceramic blocks only $250 \mathrm{~kg} \mathrm{CO}$ eq., which is by $45 \%$. As it has already been addressed above, majority of the $\mathrm{CO}_{2}$ emissions are generated by the Portland cement component in the material. 


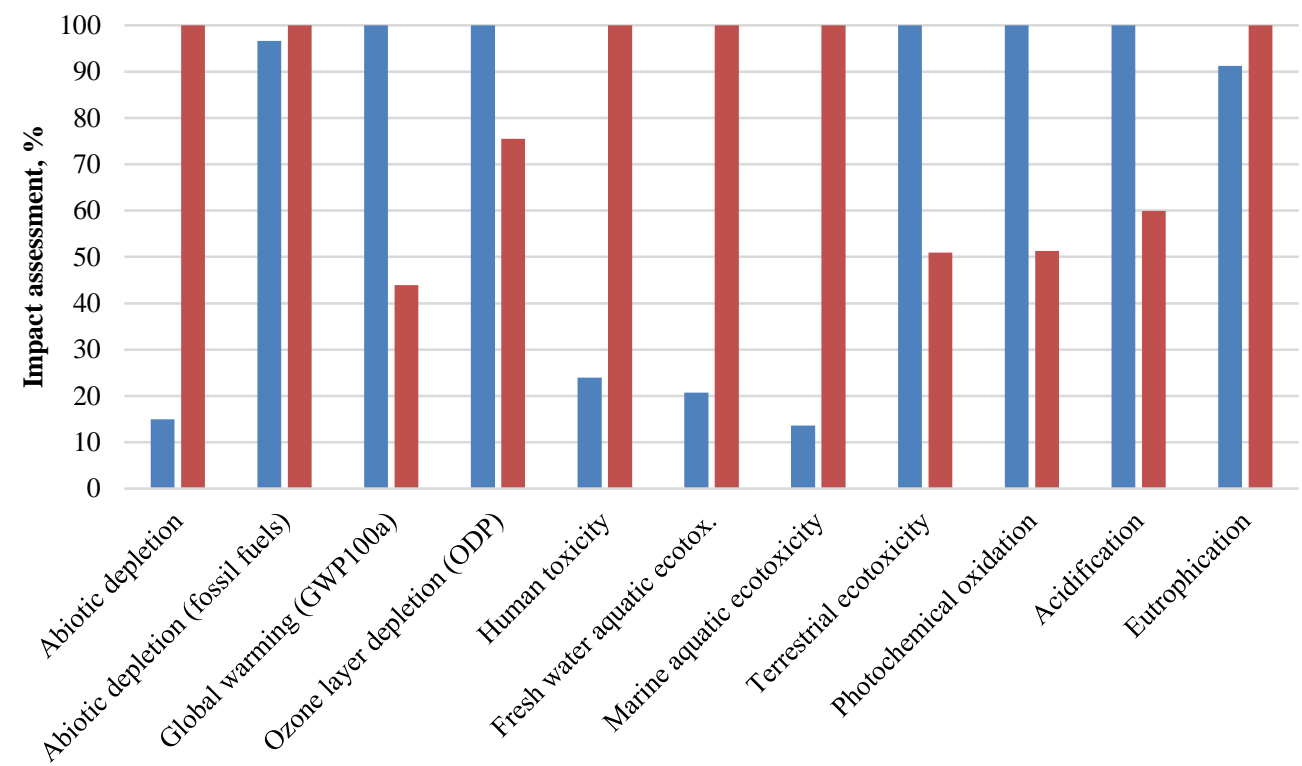

- FC-12.5 hollow ceramic block

Fig. 4. Foam concrete FC-12.5 impact assessment compared with hollow ceramic block by CML-IA baseline V3.04/EU25.

TABLE 4. COMPARING FC-12.5 AND HOLlOW CERAMIC BLOCK BY CML-IA BASELINE V3.04/EU25

\begin{tabular}{|c|c|c|c|}
\hline Impact category & Unit & FC-12.5, volume in $1 \mathrm{~m}^{3}$ & $\begin{array}{l}\text { Hollow ceramic block, } \\
\text { volume in } 1 \mathrm{~m}^{3}\end{array}$ \\
\hline Abiotic depletion & $\mathrm{kg} \mathrm{Sb}$ eq. & $7.6 \cdot 10^{-5}$ & $5.1 \cdot 10^{-4}$ \\
\hline $\begin{array}{l}\text { Abiotic depletion (fossil } \\
\text { fuels) }\end{array}$ & MJ & 2350 & 2720 \\
\hline $\begin{array}{l}\text { Global warming } \\
\text { (GWP100a) }\end{array}$ & $\mathrm{kg} \mathrm{CO} \mathrm{CO}_{2}$ eq. & 508 & 250 \\
\hline $\begin{array}{l}\text { Ozone layer depletion } \\
\text { (ODP) }\end{array}$ & kg CFC-11 eq. & $2.7 \cdot 10^{-5}$ & $2.2 \cdot 10^{-5}$ \\
\hline Human toxicity & kg 1,4-DB eq. & 18.7 & 87.4 \\
\hline $\begin{array}{l}\text { Fresh water aquatic } \\
\text { ecotox. }\end{array}$ & kg 1,4-DB eq. & 5.89 & 31.8 \\
\hline Marine aquatic ecotoxicity & kg 1,4-DB eq. & 53500 & 44000 \\
\hline Terrestrial ecotoxicity & $\mathrm{kg}$ 1,4-DB eq. & 0.473 & 0.27 \\
\hline Photochemical oxidation & $\mathrm{kg} \mathrm{C}_{2} \mathrm{H}_{4}$ eq. & 0.09 & 0.05 \\
\hline Acidification & $\mathrm{kg} \mathrm{SO}_{2}$ eq. & 1.31 & 0.87 \\
\hline Eutrophication & $\mathrm{kg} \mathrm{PO}_{4}{ }^{3-}$ eq. & 1.67 & 0.21 \\
\hline
\end{tabular}

Analysing the obtained data according to the Table 6, it can be seen that an environmental criterion of the abiotic depletion (fossil fuel), which indicates the impact of resource consumption value, differs by $14 \%$, which indicates that the production processes of the 
hollow ceramic blocks consume more energy. The lowest figures for the foam concrete FC-12.5 are in environmental impact categories, such as human toxicity as well as freshwater and marine ecotoxicity. The human toxicity from hollow ceramic block is 5 times bigger than from foam concrete, but from expanded clay concrete block impact in human toxicity is even bigger, which is 7 times higher compared with foam concrete, by SimaPro database. The impact of FC-12.5 is by 40-60\% higher compared to the hollow ceramic block in the categories that affect global warming, photochemical oxidation, environmental acidification caused by the processes related to the Portland cement production and extraction. The impact of terrestrial ecotoxicity of FC-12.5, which is equally caused by the Portland cement and metakaolin production processes, is approximately by $43 \%$ higher. FC-12.5 has by $20 \%$ higher impact in the eutrophication compared to the hollow ceramic blocks. Comparing those two materials with one mobile phone Lithium-Ion rechargeable battery environment impact, it can be seen that fresh water aquatic ecotoxicity value from $1 \mathrm{~m}^{3}$ foam concrete FC-12.5 and one Lithium-Ion battery are very close, while value from $1 \mathrm{~m}^{3}$ hollow ceramic blocks is about 5 times bigger. However, based on global warming potential by $\mathrm{CO}_{2}$ emissions the $\mathrm{FC}-12.5$ has biggest impact comparing with hollow ceramic block.

By identifying the element of foam concrete compositions having the biggest impact in global warming (Portland cement) is possible to reduce this impact. In this research Portland Cement CEM I was used, which is pure Portland cement without additives, hence, by choosing cement with additives it is possible to obtain different result in order to reduce emissions shown in the global warming potential in the Table 5. In the Table 5 different types of cement are compared by additives with same mass volume. The Portland cement for FC-12.5 is key element for compressive strength, the Table 5 shows possible replacement of Portland cement by additives, which can be used in the future research to examine foam concrete, e.g. using cement with blast furnace slag instead of pure Portland cement it is possible to reduce $\mathrm{CO}_{2}$ emissions more than 1.5 times. However, only by testing a sample of such composition it would be possible to examine its compressive strength.

\section{TABLE 5. Possible $\mathrm{CO}_{2}$ EMISSIONS USING CEMENT with AdDITIVES} FOR 1 KG FOAM CONCRETE FC-12.5

\begin{tabular}{lllll}
\hline & $\begin{array}{l}\text { Portland cements } \\
\text { CEM I 42.5 N }\end{array}$ & $\begin{array}{l}\text { Portland cements } \\
\text { CEM II }\end{array}$ & $\begin{array}{l}\text { Cement with } \\
11-35 \% \text { fly ash }\end{array}$ & $\begin{array}{l}\text { Cement with 18-35\% } \\
\text { blast furnace slag }\end{array}$ \\
\hline $\begin{array}{l}\text { Percentage breakdown by } \\
\begin{array}{l}\mathrm{CO}_{2} \text { emissions in impact } \\
\text { category GWP, }\end{array}\end{array}$ & 94.07 & 91.9 & 82.1 & 61.5 \\
$\begin{array}{l}\text { Total } \mathrm{CO}_{2} \text { emissions in } \\
\text { impact category GWP, } \\
\mathrm{kg} \mathrm{CO} \text { eq. }\end{array}$ & 0.44 & 0.41 & & 0.27 \\
\hline
\end{tabular}

\subsection{Life Cycle Assessment and its Interpretation for the Foam Concrete FC-2.4}

$1 \mathrm{~kg}$ of foam concrete FC-2.4 was assessed and analysed using the same principles as for $1 \mathrm{~kg}$ of foam concrete FC-12.5 including functional units of the LCA and emissions from their individual processes according to environmental impact significance criteria. As it can be seen from the graph (Fig. 5) and Table 6, the biggest impact is from foam glass granules used in foam concrete to improve insulation properties. The total calculated $\mathrm{CO}_{2}$ emissions from $1 \mathrm{~kg}$ of foam concrete $\mathrm{FC}-2.4$ are $0.68 \mathrm{~kg} \mathrm{CO} 2$ eq. The results show that foam glass granules represent the largest share of global warming potential (GWP), which is $0.47 \mathrm{~kg} \mathrm{CO}_{2}$ eq. The material FC-2.4 consists of $27.5 \%$ of the foam glass granules in the material composition, which accounts for about $69 \%$ of all $\mathrm{CO}_{2}$ emissions from the material. At the 
same time, Portland cement together with fly ash constitute about $50 \%$ of the mass in the composition of the material and accounts for about $27 \%\left(0.18 \mathrm{~kg} \mathrm{CO} \mathrm{CO}_{2}\right.$ eq.) of total $\mathrm{CO}_{2}$ emissions from the material.

TABLE 6. PERCENTAGe COMPARISON OF FoAM

CONCRETE FC-2.4 COMPOSITION BY CO $\mathrm{CO}_{2}$ EMISSIONS

\begin{tabular}{lll}
\hline FC-2.4 composition & $\begin{array}{l}\text { Percentage breakdown by } \\
\text { components of mass, \% }\end{array}$ & $\begin{array}{l}\text { Percentage breakdown by CO2 } \\
\text { emissions in impact category GWP, \% }\end{array}$ \\
\hline Portland cement with fly ash & 49.9 & 26.56 \\
Water & 20 & 0.01 \\
Polypropylene fibres EUROFIBER REF 512 & 0.6 & 2.14 \\
Metakaolin & 1.7 & 0.77 \\
Foam glass granules & 26.5 & 69.11 \\
Silica fume (Elkem 971Dens) & 1.3 & 0.01 \\
Plant power & - & 1.4 \\
\hline
\end{tabular}

The results of such emissions are obtained from the input data of the SimaPro program, which considers the impact of stages of material production processes. However, the energy consumption of the production of FC-2.4 has a small impact on the GWP criteria by used intensive mixing technology, which accounts only for $1.4 \%$ of $\mathrm{CO}_{2}$ emissions of the material.

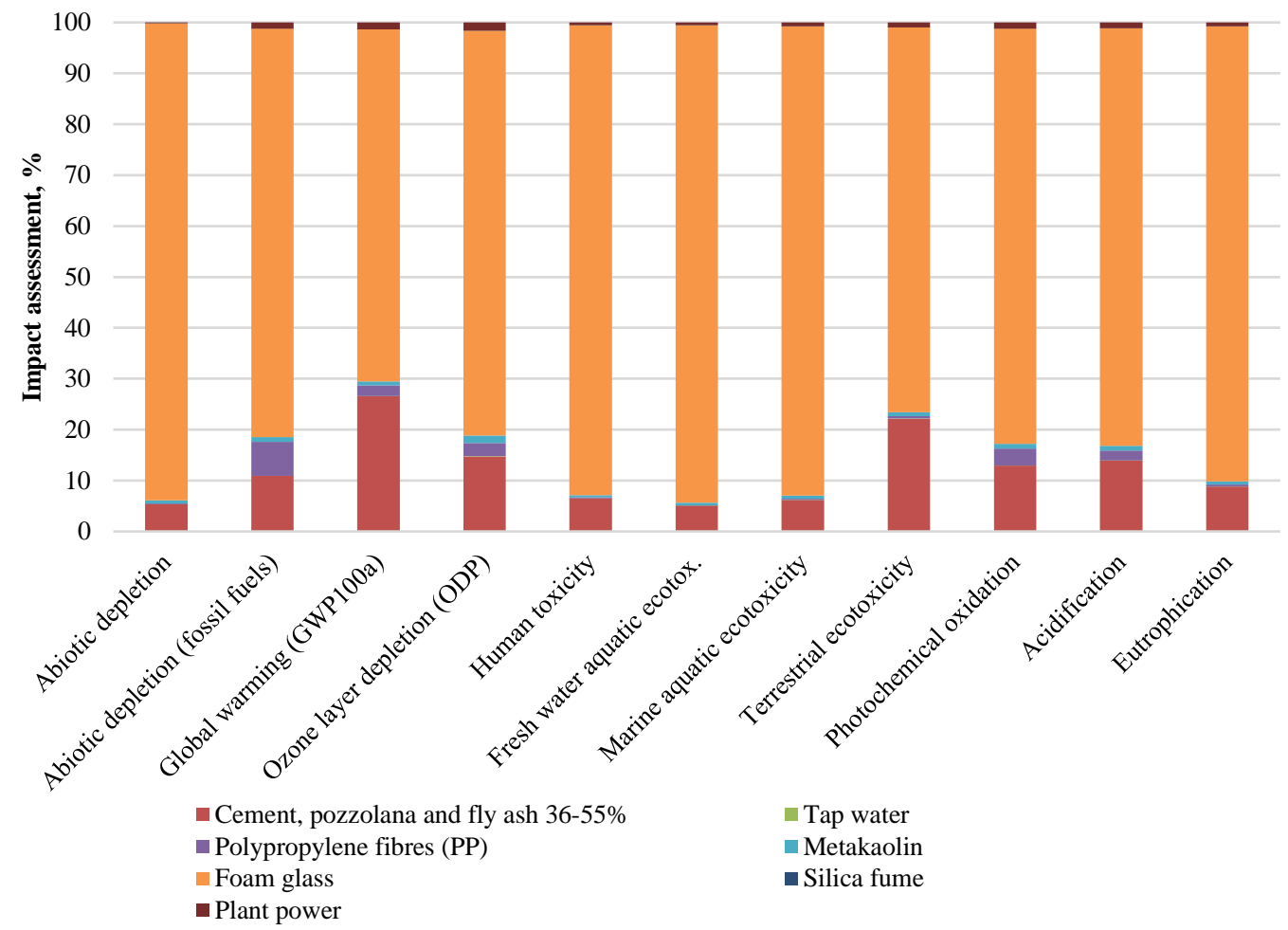

Fig. 5. Foam concrete FC-2.4 impact assessment by CML-IA baseline V3.04 / EU25. 
Foam glass granules have the highest emission factor among the components of the material. The study examines options for replacing conventional foam glass granules with foam glass granules made of recycled glass (scrap glass and glass waste), which do not require high production temperature compared to the production of foam glass and whose production process involves the recycling of glass waste that reduces $\mathrm{CO}_{2}$ emissions contributing to global warming processes. Based on the results of the study [26], which focused on the LCA of foam glass produced from scrap glass and glass waste, it is possible to conclude that the energy consumption of the foam glass production involving the use of scrap glass is by $22.4 \%$ lower compared to the glass melting process, while the $\mathrm{CO}_{2}$ emissions are by $24.8 \%$ lower and the overall environmental impact is by $40 \%$ lower. Based on the data obtained from this study, the adjustments are made to the data already obtained in the SimaPro program in order to compare the $\mathrm{CO}_{2}$ emissions from the foam glass granules (Table 7) including the glass manufacturing process and the emissions from the foam glass granules produced from waste glass and scrap glass, such as foam glass pellets from Stikloporas in Lithuania [27].

TABLE 7. $\mathrm{CO}_{2}$ EMISSIONS USING FOAM GLASS GRANULES FROM RECYCLED GLASS

\begin{tabular}{lll}
\hline & Foam glass granules & $\begin{array}{l}\text { Foam glass granules } \\
\text { from recycled glass }\end{array}$ \\
\hline $\begin{array}{l}\text { Percentage breakdown by } \mathrm{CO}_{2} \\
\text { emissions in impact category GWP, } \%\end{array}$ & 69.11 & 62.8 \\
$\begin{array}{l}\text { Total } \mathrm{CO}_{2} \text { emissions in impact category } \\
\mathrm{GWP}, \mathrm{kg} \mathrm{CO}_{2} \text { eq. }\end{array}$ & 0.679 & 0.560 \\
\hline
\end{tabular}

As a result, using the foam glass granules produced from waste glass, the $\mathrm{CO}_{2}$ emissions can be reduced by $18 \%$ for the foam concrete FC-2.4 (Table 7). Such replacement would also reduce other impact categories, as foam glass granules are the largest contributor in every impact category.

\subsection{Comparison of the Foam Concrete FC-2.4 with the Aerated Concrete Block According to the Life Cycle Assessment}

The foam concrete FC-2.4 is compared to an analogous building material chosen according to the strength and similar thermal conductivity - aerated concrete block [28]. Aerated concrete block Bauroc UNIVERSAL with a strength $2.5 \mathrm{MPa}$, with a density $375 \pm 25 \mathrm{~kg} / \mathrm{m}^{3}$ and thermal conductivity $0.090 \mathrm{~W} /(\mathrm{mK})$ have been used for the research purposes. As mentioned above in the paragraph 3.3, the material FC-2.4 is porous with low density and its thermal properties have been increased by using foam glass granules.

The obtained results are shown in the graph (Fig. 6) and Table 8, which shows a comparison between the foam concrete FC-2.4 percentage to that of the aerated concrete block. It can be seen that foam concrete production processes generate higher emissions in all environmental impact categories. According to the environmental impact criteria, which characterizes the global warming potential (GWP), it can be seen that $1 \mathrm{~m}^{3}$ of FC-2.4 material produces $302 \mathrm{~kg} \mathrm{CO} 2$ eq., but aerated concrete blocks only $189 \mathrm{~kg} \mathrm{CO}_{2}$ eq., which is by $37 \%$ lower. 


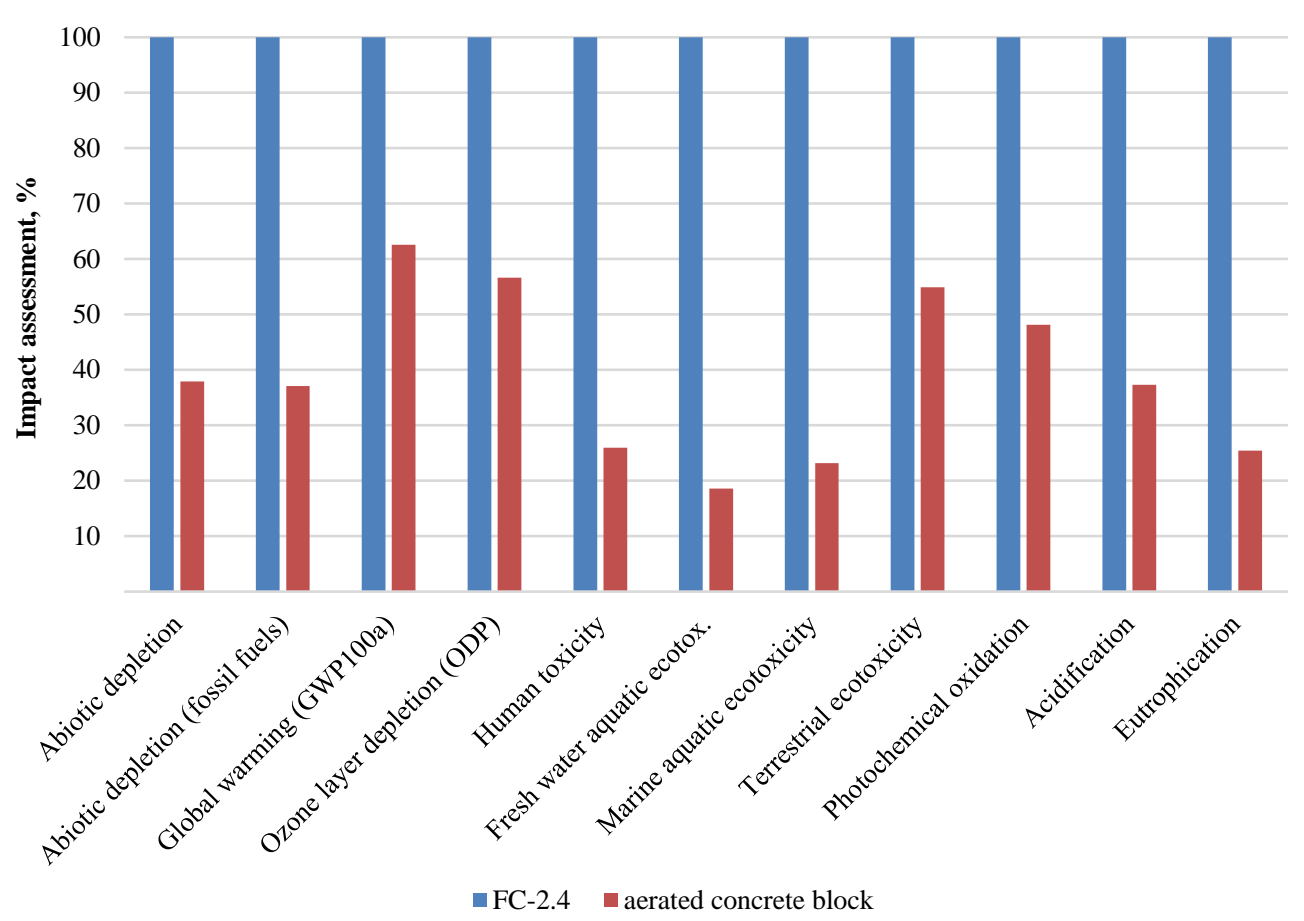

Fig. 6. Foam concrete FC-2.4 impact assessment compared with aerated concrete block by CML-IA baseline V3.04/EU25.

TABLE 8. COMPARING FC-2.4 AND AERATED CONCRETE BLOCK
BY CML-IA BASELINE V3.04/EU25

\begin{tabular}{|c|c|c|c|}
\hline Impact category & Unit & FC-2.4, volume in $1 \mathrm{~m}^{3}$ & $\begin{array}{l}\text { Aerated concrete block, } \\
\text { volume in } 1 \mathrm{~m}^{3}\end{array}$ \\
\hline Abiotic depletion & $\mathrm{kg} \mathrm{Sb}$ eq. & $8 \cdot 10^{-4}$ & $3 \cdot 10^{-4}$ \\
\hline $\begin{array}{l}\text { Abiotic depletion (fossil } \\
\text { fuels) }\end{array}$ & MJ & 3276 & 1215 \\
\hline $\begin{array}{l}\text { Global warming } \\
\text { (GWP100a) }\end{array}$ & $\mathrm{kg} \mathrm{CO}_{2}$ eq. & 302 & 189 \\
\hline $\begin{array}{l}\text { Ozone layer depletion } \\
\text { (ODP) }\end{array}$ & $\mathrm{kg}$ CFC-11 eq. & $1.8 \cdot 10^{-5}$ & $1 \cdot 10^{-5}$ \\
\hline Human toxicity & $\mathrm{kg}$ 1.4-DB eq. & 129.9 & 33.7 \\
\hline $\begin{array}{l}\text { Fresh water aquatic } \\
\text { ecotox. }\end{array}$ & kg 1.4-DB eq. & 107 & 20 \\
\hline Marine aquatic ecotoxicity & kg 1.4-DB eq. & 342586 & 79463 \\
\hline Terrestrial ecotoxicity & kg 1.4-DB eq. & 0.46 & 0.25 \\
\hline Photochemical oxidation & $\mathrm{kg} \mathrm{C}_{2} \mathrm{H}_{4}$ eq. & 0.06 & 0.03 \\
\hline Acidification & $\mathrm{kg} \mathrm{SO}_{2}$ eq. & 1.29 & 0.48 \\
\hline Eutrophication & $\mathrm{kg} \mathrm{PO}_{4}{ }^{3-}$ eq. & 0.50 & 0.13 \\
\hline
\end{tabular}


Analysing the obtained data according to the Table 8, it can be seen that the overall impact of both compared materials on abiotic depletion, ozone depletion, photochemical oxidation, acidification of the environment and eutrophication is small, (even if FC-2.4 creates more impact resulting from the production processes of Portland cement and foam glass granules compared with the aerated concrete block), where the units of impact equivalent to $\mathrm{kg}$ are indicated by $1 \mathrm{~m}^{3}$ of the material. In the environmental criteria for emissions from FC -2.4 material, abiotic depletion (fossil fuels), toxicity to humans as well as freshwater and marine ecotoxicity are by 60-80\% higher compared to the aerated concrete. This impact results from the extraction and production processes of foam glass granules and Portland cement.

The major component of FC-2.4, which affects the total emissions, is foam glass granules contributing to the high thermal properties of the material. For this reason, it is necessary to include the foam glass made from scrap glass and glass waste in the comparison, which has already been addressed in this work (see Table 7). As a result, the use of foam glass granules made of scrap glass and glass waste in the FC-2.4 material reduces $\mathrm{CO}_{2}$ emissions having an impact on the global warming by $18 \%$ compared to $\mathrm{FC}-2.4$ without glass granules produced from glass waste. Even adding smaller amount of the foam glass granules in the FC-2.4 and thus reducing the $\mathrm{CO}_{2}$ emissions of such foam glass, the material still has by $23 \%$ more $\mathrm{CO}_{2}$ emissions compared to the aerated concrete block.

\section{Conclusions}

Analysing by LCA two foam concrete compositions with different compressive strengths the data of the amount of $\mathrm{CO}_{2}$ emissions from each foam concrete component which affects environmental pollution have been obtained. The result of foam concrete with compressive strengths $12.5 \mathrm{MPa}$ (FC-12.5) shows that biggest impact on the environment from the $\mathrm{CO}_{2}$ emissions comes from the Portland cement, which is used in foam concrete to increase its compressive strength. The result of foam concrete with compressive strengths $2.4 \mathrm{MPa}$ (FC-2.4) shows that the biggest impact on environment comes from the foam glass granules compared to Portland cement with flay ash additives, which is used to improve insulation properties. However, insignificant impact on the GWP criteria comes from the production process of the foam concrete, which confirms that by using intensive mixing technology low environmental impact is achieved.

By comparing foam concrete with analogue material by compressive strength according to Global warming potential criteria, the result shows that lower impact on environment comes from analogue materials than from the examined foam concrete. The results obtained in the LCA regarding the impact on global warming showed by $51 \%$ higher levels of $\mathrm{CO}_{2}$ emissions for FC-12.5 compared to an analogue material - hollow ceramic block "Keraterm 38" according to the strength criteria. The levels of $\mathrm{CO}_{2}$ emissions are based on the Portland cement used, which is a key element in this composition, in order to obtain the strength of the foam concrete FC-12.5. Portland cement (46\% in the foamed concrete) accounts for $94 \%$ of all $\mathrm{CO}_{2}$ emissions, as well as metakaolin (only $3.3 \%$ in the foamed concrete), which accounts for only $2.4 \%$ of the $\mathrm{CO}_{2}$ emissions from the material.

The foam concrete FC-2.4 has by $37 \%$ higher $\mathrm{CO}_{2}$ emission levels and the global warming impact than aerated concrete, which mainly comes from the foam glass granules used to improve the thermal properties of the material. The material FC-2.4 consists of $27.5 \%$ of the foam glass granules in the material composition, which accounts for about $69 \%$ of all $\mathrm{CO}_{2}$ emissions from the material. At the same time, Portland cement together with fly ash constitute about $50 \%$ in the composition of the material and accounts for about $27 \%$ of total 
$\mathrm{CO}_{2}$ emissions from the material. By using foam glass granules, which is made from scrap glass and glass waste, in the production of the foam concrete FC-2.4, it is possible to reduce the total $\mathrm{CO}_{2}$ emissions by $23 \%$.

The results showed that foam concrete has bigger impact on the environment than analogue materials according to the compressive strength criteria. This research that examine two types of foam concrete with different compressive strength shows the ability to improve and develop foam concrete mix with less impact in environment. By replacing or adding components to foam concrete it is possible to reduce impact on global warming potential, for example, replacing cement with fly ash, blast furnace slag, glass powder to reduce impact from Portland cement component and replacing foam glass granules with foam glass granules from recycled glass.

\section{ACKNOWLEDGEMENT}

The financial support of European Regional Development Fund project Nr.1.1.1.1/16/A/007 “A New Concept for Sustainable and Nearly Zero-Energy Buildings" is acknowledged.

\section{REFERENCES}

[1] UNEP SBCI. Buildings and Climate Change. Summary for Decision-Makers. Paris: DTIE, 2009.

[2] Wolf C., Pomponi F., Moncaster A. Measuring embodied carbon dioxide equivalent of buildings: A review and critique of current industry practice. Energy Build 2017:140:68-80. doi:10.1016/j.enbuild.2017.01.075

[3] European Union. Directive 2010/31/EU of the European parliament and council on the energy performance of buildings. Official Journal of the European Union 2010:L153/13.

[4] Genovaite L., Mindaugas B. The European Union possibilities to achieve targets of Europe 2020 and Paris agreement climate policy. Renewable Energy 2017:106:298-309. doi:10.1016/j.renene.2017.01.036

[5] Brojan L., Petric A., Clouston P. L. A comparative study of brick and straw bale wall systems from environmental, economical and energy perspectives. ARPN Journal of Engineering and Applied Sciences 2013:8(11):920-926.

[6] Sinka M., et al. Comparative life cycle assessment of magnesium binders as an alternative for hemp concrete. Resources conservation and recycling 2018:133:288-299. doi:10.1016/j.resconrec.2018.02.024

[7] Suhendro B. Toward Green Concrete for Better Sustainable Environment. Procedia Engineering 2014:95:305-320. doi:10.1016/j.proeng.2014.12.190

[8] Siram K. K. B., Raj K. A. Concrete + Green = Foam Concrete. International Journal of Civil Engineering and Technology 2013:4(4):179-184.

[9] Ramamurthy K., Nambiar E. K., Ranjani G. I. S. A classification of studies on properties of foam concrete. Cement and Concrete Composites 2009:31(6):388-396. doi:10.1016/j.cemconcomp.2009.04.006

[10] Khan Q. S., et al. Experimental investigation on foam concrete without and with recycled glass powder: A sustainable solution for future construction. Construction and Building Materials 2019:201:369-379. doi:10.1016/j.conbuildmat.2018.12.178

[11] Gökçe H. S., Hatungimana D., Ramyar K. Effect of fly ash and silica fume on hardened properties of foam concrete. Construction and Building Materials 2019:194:1-11. doi:10.1016/j.conbuildmat.2018.11.036

[12] Falliano D., et al. Experimental investigation on the compressive strength of foamed concrete: Effect of curing conditions, cement type, foaming agent and dry density. Construction and Building Materials 2018:165:735-749. doi:10.1016/j.conbuildmat.2017.12.241

[13] Hertz K. $\mathrm{CO}_{2}$ emissions from super-light structures. Lyngby: Technical University of Denmark, 2010.

[14] Heijungs R. Ecodesign - Carbon Footprint — Life Cycle Assessment — Life Cycle Sustainability Analysis. A Flexible Framework for a Continuum of Tools. Environmental and Climate Technologies 2010:4(1):42-46. doi:10.2478/v10145-010-0016-5

[15] ISO 14040:2006. Environmental Management - Life Cycle Assessment - Principles and Framework, 2006.

[16] ISO 14044:2006. Environmental management - Life cycle assessment - Requirements and guidelines, 2006.

[17] Goedkoop M., et al. Introduction to LAC with SimaPro. Pre, 2016.

[18] Guinée J. B., et al. Handbook on life cycle assessment operational guide to the ISO standards. I: LCA in perspective. The International Journal of Life Cycle Assessment 2002:7:311. doi:10.1007/BF02978897

[19] Acero A. P., Rodríguez C., Ciroth A. LCIA methods Impact assessment methods in Life Cycle Assessment and their impact categories. Berlin: Greendeta, 2017 
[20] Namsone E., Šahmenko G., Korjakins A. Durability Properties of High Performance Foamed Concrete. Procedia Engineering 2017:172:760-767. doi:10.1016/j.proeng.2017.02.120

[21] Namsone E., Korjakins A., Šahmenko G., Šinka M. The Environmental Impacts of Foamed Concrete Production and Exploitation. IOP Conference Series: Materials Science and Engineering 2017:251:20-29. doi:10.1088/1757-899X/251/1/012029

[22] Heath A. C., Paine K. A., McManus M. C. Minimising the global warming potential of clay based geopolymers. Journal of Cleaner Production 2014:78:75-83. doi:10.1016/j.jclepro.2014.04.046

[23] Mahmud M. A. P., Huda N., Farjana S. H., Lang C. Comparative Life Cycle Environmental Impact Analysis of Lithium-Ion (LiIo) and Nickel-Metal Hydride (NiMH) Batteries. Batteries 2019:5(1):22. doi:10.3390/batteries5010022

[24] Bricks, pavement, building blocks company Lode [Online]. [Accessed 11.01.2019]. Available: https://lode.lv/produkts/keraterm-44-s/

[25] Nagy B., Tóth E. Hydrothermal behaviour of hollow and filled ceramic masonry block. Presented at the International RILEM Conference on Materials, Systems and Structures in Civil Engineering Conference segment on Moisture in Materials and Structures, 2016 Lyngby, Denmark, 2016:279-289.

[26] Gong X. Z., Tian Y. L., Zhang L. J. A Comparative Life Cycle Assessment of Typical Foam Glass Production. Materials Science Forum 2018:913:1054-1061. doi:10.4028/www.scientific.net/MSF.913.1054

[27] Invent company Stikloporas [Online]. [Accessed 15.01.2019]. Available: http://www.stikloporas.lt/

[28] Company Bauroc [Online]. [Accessed 11.01.2019]. Available: https:// bauroc.lv/product/universal/ 